\title{
CORPORATE SOCIAL RESPONSIBILITY SEBAGAI STRATEGI MARKETING PUBLIC RELATIONS (STUDI KASUS PROGRAM CSR VAKSINASI COVID-19 DI UNIMUS)
}

\author{
Anggry Windasari, Reni Shinta Dewi \\ Universitas Diponegoro Semarang, Indonesia \\ Magister Ilmu Komunikasi, Fakultas Ilmu Sosial dan Ilmu Politik, Universitas \\ Diponegoro Semarang, Indonesia \\ Email: anggrywindasari@students.undip.ac.id, renishintadewi@lecturer.undip.ac.id
}

\begin{abstract}
Abstrak
Lemahnya sektor ekonomi akibat Covid-19 berdampak pada sektor lain seperti pendidikan, sosial, dan budaya, membuat UNIMUS harus bekerja keras untuk bersaing dengan perguruan tinggi lain. Strategi yang dilakukan adalah Marketing Public Relations dalam bentuk Corporate Social Responsibility. Dengan adanya MPR diharapkan dapat menciptakan, meningkatkan dan memperkuat brand UNIMUS yang memiliki citra dan reputasi yang baik. Tujuan dari penelitian ini adalah untuk mendeskripsikan bagaimana strategi MPR yang dilakukan Humas UNIMUS dalam meningkatkan citra dan brand untuk mendorong peningkatan jumlah penerimaan mahasiswa di masa pandemi Covid-19. Penelitian ini menggunakan metode penelitian kualitatif dengan pengumpulan data melalui wawancara, observasi dan dokumentasi. Hasil penelitian menunjukkan bahwa ada tiga jenis strategi MPR yang diterapkan, yaitu Pull Strategy, Push Strategy, dan Pass Strategy. Pull Strategi berupa digital flyer, banner, backdrop, brosur, dan video. Push Strategy dilakukan dengan melakukan publikasi di berbagai media seperti koran, TV, dan media digital. Strategi Pass ditunjukkan dengan memberikan pelayanan prima kepada tim vaksinasi sehingga protokol kesehatan, ketertiban, dan kenyamanan peserta vaksin tetap terjaga serta, penyediaan gedung karantina atau isolasi mandiri bagi warga yang terkonfirmasi positif Covid-19.
\end{abstract}

Kata kunci: CSR; pemasaran; hubungan masyarakat; vaksinasi; karantina

\section{Abstract}

The weak economic sector effect from Covid-19 has an impact on other sectors such as education, social, and culture, make UNIMUS have to work hard to compete with other universities. The strategy was Marketing Public Relations in the form of Corporate Social Responsibility. With the MPR, it was expected to create, increase and strengthen the UNIMUS brand that has a good image and reputation. The purpose of this research was to describe how the MPR strategy carried out by Public Relations of UNIMUS in improving the image and brand to encourage an increase in the number of student admissions in the Covid-19

$\begin{array}{ll}\text { How to cite: } & \text { Dewi R. S., Windasari. A. (2021) Corporate Social Responsibility Sebagai Strategi Marketing Public } \\ & \text { Relations (Studi Kasus Program CSR Vaksinasi Covid-19 di Unimus). Syntax Literate: Jurnal Ilmiah } \\ & \text { Indonesia, 6(2) } \\ \text { E-ISSN: } & \text { 2548-1398 } \\ \text { Published by: } & \text { Ridwan Institute }\end{array}$


pandemic. This research used qualitative research method by collecting data from interview, observations and documentation. The results indicate that there were three types of MPR strategies implemented, namely Pull Strategy, Push Strategy, and Pass Strategy. Pull Strategies were in the form of digital flyers, banners, backdrops, brochures, and videos. Push Strategy was carried out by publishing in various media such as newspapers, TV, and digital media. Pass Strategy showed by providing excellent service for the vaccination team therefore health protocol, orderliness, and comfort of vaccine participants were maintained as well as, provision of quarantine or self-isolation buildings for the citizen who was confirmed positive for Covid-19.

Keywords: CSR; marketing; public relations; vaccination; quarantine

Received: 2021-10-20; Accepted: 2021-11-05; Published: 2021-11-20

\section{Pendahuluan}

Akhir tahun 2019 dunia dikejutkan dengan adanya virus yang menyebabkan penyakit Covid-19. Virus tersebut dinamakan sebagai SARS-COV2 (Severe Acute Respiratory Syndrome Coronavirus 2 yang termasuk salah satu jenis coronavirus. (who.int/indonesia, 2020). Virus tersebut menyebabkan jutaan korban di berbagai negara termasuk di Indonesia. Di negara Indonesia sendiri, data per 24 Juli 2021 menunjukan sebanyak 2.379.397 orang positif terinfeksi Covid-19. Selain itu, dilaporkan pula orang yang sembuh sebanyak 1.973.388 serta 62.908 orang dinyatakan meninggal dunia (covid19.go.id, 2021). Adanya pandemi Covid-19 tentu memukul berbagai sektor seperti sektor sosial, budaya, pendidikan dan terutamanya sektor ekonomi yang mengalami hantaman yang cukup luar biasa. Data Badan Pusat Statistik (BPS) mencatat bahwa konsumsi rumah tangga yang awalnya 5,02 persen di kuartal I tahun 2019 menjadi 2,84 di kuartal yang sama di tahun 2020. Lebih lanjut, pandemi Covid-19 juga mengakibatkan tingkat investasi melemah mengingat adanya ketidakpastian kapan selesainya di berbagai negara sehingga menyebabkan turunnya harga komoditas dan ekspor negara Indonesia terhenti (Statistik, 2020).

Berangkat dari hal tersebut, pemerintah Republik Indonesia melakukan berbagai upaya untuk menekan tingginya kasus Covid-19. Selain adanya kebijakan PPKM (Pemberlakuan Pembatasan Kegiatan Masyarakat) Darurat di sejumlah daerah, pemerintah RI juga melakukan intervensi yang lain seperti penerapan protokol kesehatan 5M (memakai masker, mencuci tangan, menjaga jarak, menjauhi kerumuman dan mengurangi mobilitas) sebagai upaya untuk memutus rantai penularan virus corona tersebut. Serta upaya vaksinasi Covid-19 yang tidak hanya untuk mengurangi penyebaran virus corona akan tetapi juga untuk mencapai kondisi herd immunity (kekebalan kelompok) di masyarakat sehingga diharapkan akan lebih memberikan perlindungan ekstra agar kesehatan yang berimbas kepada produktivitas masyarakat terjaga (WHO, 2021). Selain itu, upaya vaksinasi yang dipandang sebagai tindakan pencegahan jauh lebih hemat anggaran jika dibandingkan dengan upaya pengobatan. Oleh karenanya, upaya pemerintah tersebut perlu mendapatkan dukungan dari berbagai 
pihak seperti masyarakat sendiri (publik), media/pers, perguruan tinggi, ormas, dan lain sebagainya agar pelaksanaan vaksinasi Covid-19 berjalan optimal.

Universitas Muhammadiyah Semarang (UNIMUS) sebagai salah satu Perguruan Tinggi Swasta Islam di Indonesia mentargetkan perolehan mahasiswa baru tahun akademik 2020/2021 sebanyak 3.000. Akan tetapi pada kenyataannya penerimaan mahasiswa baru yang dilantik oleh Rektor per September 2020 hanya 2.430 saja (Kehumasan Unimus, 2020). UNIMUS yang memiliki fungsi pendidikan dituntut tetap "hidup (menghasilkan)" namun juga tidak boleh komersil, harus memutar otak untuk tetap menjalankan roda organisasi. UNIMUS menjalankan operasionalnya dari biaya pendidikan yang dibayarkan oleh mahasiswa. Oleh karenanya UNIMUS mengeluarkan kebijakan seperti adanya potongan harga, berbagai macam beasiswa, sistem pembayaran yang bisa diangsur dan lain-lainnya sebagai upaya relaksasi biaya (Kehumasan Unimus, 2020). Kebijakan-kebijakan tersebut tentu harus optimal dikomunikasikan ke publik agar masyarakat menjadikan UNIMUS sebagai perguruan tinggi pilihan untuk melanjutkan studi khususnya dalam kondisi ekonomi lemah di tengah pandemi Covid-19 saat ini. Salah satu bentuk komunikasi tersebut adalah dengan adanya promosi ke publik yakni menggunakan strategi Marketing Public Relations (MPR). Pengertian Marketing Public Relations (Ruslan, 2010) adalah serangkaian proses dari mulai perencanaan, pelaksanaan hingga evaluasi dimana program-program MPR tersebut berisikan penyampaian informasi yang kredibel dan valid mengenai produk atau jasa/layanan suatu perusahaan sehingga dapat dipercaya oleh publik dan merangsang peningkatan penjualannya. Dari definisi tersebut poin pentingnya adalah pada pemberian informasi faktual yang bisa menciptakan "trust" dari masyarakat (poin public relations) serta menstimulasi peningkatan penjualan atau pendaftaran (poin marketing).

Dalam melaksanakan agenda marketing public relations dibutuhkan strategi atau taktik yakni pull strategy (strategi menarik), push strategy (strategi mendorong) dan pass strategy (strategi mempengaruhi serta menciptakan pendapat publik) (Ruslan, 2010). Pull strategy biasanya dilakukan dalam bentuk iklan atau promosi melalui media dikarenakan sifatnya bisa untuk menarik attention publik. Push strategy digunakan untuk mendorong audience agar dapat menstimulasi penjualan atau pendaftaran seperti mengadakan event/kegiatan, campaign, promo spesial dan lain sebagainya. Sedangkan pass strategy lebih mengarah ke upaya menciptakan opini publik yang menguntungkan, seperti melakukan kegiatan sosial atau berpartisipasi dalam agenda kemasyarakatan (Ruslan, 2010).

Salah satu bentuk Marketing Public Relations adalah program Corporate Social Responsibility (CSR) yang merupakan suatu program komitmen suatu perusahaan untuk turut berkontribusi secara sosial terhadap lingkungan dan masyarakat sekitarnya. Jadi perusahaan tidak hanya berorientasi terhadap profit atau keuntungan semata tetapi juga untuk pembangunan sosial secara berkelanjutan. Program Corporate Social Responsibility tidak hanya bersifat wajib bagi perusahaan akan tetapi justru malah menjadi investasi nama baik di masyarakat (Suharto, 2008). 
Program Corporate Social Responsibility yang dijalankan oleh UNIMUS adalah program vaksinasi massal (vaksinasi Covid-19) kepada 3.500 warga kota Semarang yang diselenggarakan pada tanggal 13-15 Juli 2021 (tahap 1) dan 13-14 Agustus 2021 (tahap 2). Berlokasi di Gedung Serba Guna UNIMUS, acara vaksinasi massal tersebut dibuka oleh Walikota Semarang, Hendrar Prihadi (Suara Merdeka, 2021). Bekerja sama dengan Muhammadiyah Covid-19 Command Center (MCCC), Kementerian Kesehatan Republik Indonesia, Dinas Kesehatan Provinsi Jateng dan kota Semarang serta tokoh lintas agama, acara tersebut juga dihadiri oleh Gubernur Jawa Tengah, Ganjar Pranowo. Ganjar sangat mengapresiasi vaksinasi massal yang digelar oleh UNIMUS. Pasalnya, acara tersebut terselenggara dengan teratur, tidak menimbulkan kerumunan, tertib dan antusias masyarakat sendiri begitu tinggi. Selain itu, vaksinasi juga dilaksanakan dengan penerapan protokol kesehatan yang sangat ketat sehingga dalam satu hari dapat melayani lebih dari 1.000 orang.

Penelitian sebelumnya terkait dengan program Corporate Social Responsibility sebagai perwujudan dari Marketing Public Relations telah dilakukan oleh Putri dan Aji (2019). Dalam penelitiannya, disebutkan bahwa PT Inti Daya Guna Aneka Warna membuat program CSR "Decofresh Warnai Jodipan" sebagai bagian dari kegiatan Marketing Public Relations perusahaannya. Adapun CSR tersebut adalah dilakukannya gerakan mewarnai kampung diberbagai daerah seperti di Malang, Kota Batu, Surabaya dan Banyuwangi sebagai upaya soft selling peningkatan penjualan produk cat perusahaan tersebut. Penelitian selanjutnya dilakukan oleh Widuhung (2021) dengan judul "Strategi Marketing Public Relations Petromindo Group di Era Pandemi Covid19. Dalam penelitiannya disebutkan bentuk CSR dalam Marketing Public Relations di perusahaan Petromindo Group diantaranya adalah berkunjung ke tempat klien, sponsorship, memberikan potongan harga dan penggunaan sosial media untuk media promosi.

Penelitian terkait Marketing Public Relations dalam wujud Corporate Social Responsibility telah banyak dilakukan oleh berbagai peneliti, akan tetapi masih jarang penelitian yang menggunakan konsep CSR dalam bentuk Vaksinasi Covid-19 sehingga ini menjadi kebaruan/originalitas penelitian. Berdasarkan latar belakang tersebut, peneliti tertarik untuk mengkaji lebih dalam terkait bagaimana program Corporate Social Responsibility yang dapat digunakan sebagai strategi Marketing Public Relations UNIMUS dengan menggunakan konsep three ways strategy oleh (Ruslan, 2010).

\section{Metodologi Penelitian}

Penelitian pada artikel ini menggunakan metode penelitian kualitatif yang bersifat deskriptif dengan menggunakan pendekatan studi kasus. Hal ini dikarenakan penelitian ini untuk menggambarkan atau mendeskripsikan suatu realitas sosial yang dapat diamati mengenai tindakan, perilaku atau tingkah laku yang dilakukan oleh pelaku sosial, dimana hasilnya lebih menitikberatkan narasi atau kata-kata dibandingkan dengan data statistik. Hal ini sesuai dengan pandangan Moleong (2007) yang mendefinisikan penelitian kualitatif sebagai penelitian yang digunakan untuk 
memahami situasi sosial dengan deskripsi realita secara benar dalam bentuk kata-kata (bukan data kuantitatif) berdasarkan analisis data dengan menggunakan metode ilmiah.

Studi kasus menggali lebih dalam informasi yang bisa dipelajari dari sebuah identifikasi kasus yang dalam hal ini adalah perwujudan Marketing Public Relations UNIMUS dalam bentuk Corporate Social Responsibility Vaksinasi Massal Covid-19. Wahyuningsih (2013) memaparkan penelitian yang digunakan untuk menggali suatu kasus dari fenomena tertentu dalam kurun waktu tertentu dan kegiatan/program (even, organisasi, institusi atau kelompok sosial) tertentu dengan cara pengumpulan informasi secara komprehensif, detail dan mendalam sebagai pengertian dari penelitian studi kasus. Lebih lanjut Creswell (2010) turut mengemukakan pandangan mengenai studi kasus yakni sebuah eksplorasi dari suatu sistem atau suatu kasus/peristiwa/aktivitas pada periode tertentu melalui pengumpulan data dan informasi yang mendalam.

Data dalam penelitian ini diperoleh dengan menggunakan metode melalui hasil wawancara, observasi dan juga dokumentasi. Wawancara dilakukan dengan empat narasumber yaitu Ketua Program Vaksinasi Covid-19 UNIMUS, Kepala Humas UNIMUS, perwakilan masyarakat domisili Semarang (umum) serta perwakilan lintas agama. Untuk observasi pada penelitian ini dilakukan dengan cara mengamati kinerja Humas (Public Relations) UNIMUS dalam mengelola serta mengkomunikasikan program Corporate Social Responsibility Vaksinasi Massal Covid-19 sebagai perwujudan dari strategi Marketing Public Relations dari UNIMUS. Lebih lanjut, perolehan data dengan dokumentasi dengan cara mengumpulkan gambar, foto, grafis, banner, flyer, teaser, video maupun dokumen lainnya mengenai kegiatan Humas UNIMUS terkait dengan Corporate Social Responsibility dan Marketing Public Relations. Analisis data dalam penelitian ini menggunakan model yang dipaparkan oleh Miles dan Huberman (Sugiyono, 2013) yakni reduksi data, triangulasi serta penarikan kesimpulan.

\section{Hasil dan Pembahasan}

Dalam penelitian ini, UNIMUS mengembangkan teori Marketing Public Relations (MPR) yang dikenalkan oleh Ruslan (2010), dimana teori tersebut diwujudkan dalam kegiatan Corporate Social Responsibility (CSR) yang diimplementasikan dalam kegiatan layanan publik yaitu program vaksinasi Covid-19. Kegiatan vaksinasi massal tersebut sebagai bentuk kepedulian sosial UNIMUS di tengah wabahnya virus Covid-19 agar masyarakat kota Semarang mencapai herd community sehingga lebih terlindungi dari bahaya virus corona tersebut. Hal ini menandakan prakterk kegiatan Corporate Social Responsibility (CSR) UNIMUS adalah model "protecting”.

Sementara itu, strategi Marketing Public Relations yang diterapkan dalam kegiatan Corporate Social Responsibility (CSR) tersebut djabarkan menjadi tiga strategi yakni pull strategy, push strategy dan pass strategy. Adapun paparannya adalah sebagai berikut ini : 
a. Pengembangan Materi Pull Strategy Berbasis Program CSR Vaksinasi

Didalam konsep Marketing Public Relations program vaksinasi Covid-19 yang pertama adalah pull strategy yakni strategi untuk menarik perhatian (atensi) masyarakat melalui teknik komunikasi dan promosi yang informatif dan unik. UNIMUS menggunakan iklan dan promosi untuk dapat meningkatkan brand awareness publik terhadap institusi. Iklan dan promosi yang dibuat oleh UNIMUS digunakan untuk menarik minat masyarakat yang dituangkan dalam media konvensional maupun media digital. Media konvensional seperti baliho, brosur, banner, backdrop dan lain sebagainya. Sedangkan media digital, UNIMUS menggunakan media sosial. Dalam iklan dan promosi yang dibuat oleh UNIMUS memuat lebih banyak materi tentang product knowledge perguruan tinggi seperti daftar program studi, fakultas, akreditasi unggul, serta sarana dan prasarana. Namun ketika melakukan beberapa program CSR, materi promosi yang dibuat oleh UNIMUS lebih mengarah ke program CSR tersebut. Salah satunya adalah program CSR vaksinasi Covid-19. Target peserta vaksinasi adalah masyarakat khususnya kota Semarang yang berusia diatas 17 tahun atau bahasa sederhananya adalah mereka yang sudah memiliki Kartu Tanda Penduduk (KTP). Hal ini sesuai pula dengan sasaran atau target market UNIMUS, dimana penerimaan mahasiswa barunya adalah siswa SMA tingkat akhir dimana rata-rata usia sekitar 17-18 tahun. Dalam promosi UNIMUS dalam bentuk CSR vaksinasi Covid-19 konten yang digunakan adalah flyer digital yang disebarluaskan melalui media sosial UNIMUS yakni Instagram, Facebook, dan Whasapp. Flyer digital tersebut berisikan info mengenai pendaftaran vaksinasi di UNIMUS. Lebih dari 3.500 orang mendaftar setelah flyer digital tersebut disebarluaskan.

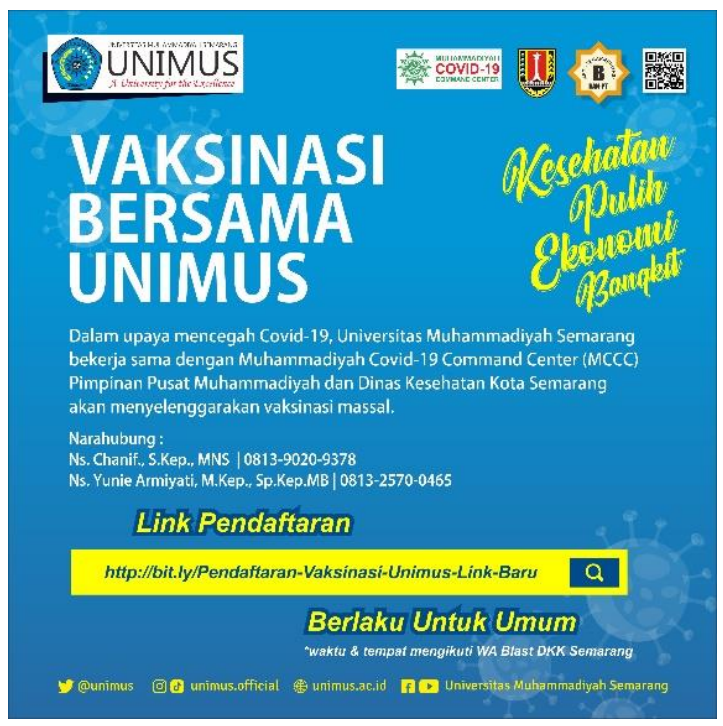

Gambar 1

Flyer Digital Vaksinasi di UNIMUS

Pada saat hari H-nya vaksinasi, strategi pull strategy juga tersedia dalam bentuk MMT/backdrop, banner dan brosur. Dalam brosur, selain terdapat informasi tentang vaksinasi, terselip juga informasi mengenai UNIMUS seperti informasi mengenai penerimaan mahasiswa baru tahun akademik 2021/2022, dimana terdapat 28 program 
studi dan 8 fakultas unggulan yang siap menerima peserta didik baru. Lebih lanjut konten dalam bentuk video pun juga dibuat yakni live streaming melalui zoom dan youtube yang menghadirkan langsung Walikota Semarang, Hendrar Prihadi. Video teaser singkat dari hari pertama hingga hari terakhir pun selalu dibuat oleh tim humas UNIMUS. Diantaranya terdapat video mengenai kunjungan mendadak oleh Gubernur Jawa Tengah, Ganjar Pranowo. Meskipun mendadak, Gubernur Jawa Tengah tetap memberikan apresiasi dan komentar positif mengenai pelaksanaan vaksinasi di UNIMUS. Karena tergolong tertib, cepat, tidak menimbulkan kerumunan, dan bahkan bisa menjadi contoh bagi sentra vaksin lainnya. Dengan flyer, banner, MMT, brosur maupun video tersebut masyarakat di kota Semarang sangat antusias. Terbukti dengan realisasi pendaftar yang datang memenuhi kuota sebanyak lebih dari 3.500 orang dalam waktu tiga hari (tahap pertama) dan dua hari (tahap kedua).

b. Perwujudan Push Strategy Berbasis Program CSR Vaksinasi

Strategi ini merupakan strategi untuk merangsang atau mendorong publik serta menciptakan image positif perusahaan. Dalam hal ini UNIMUS melakukan strategi yakni dengan mengadakan event-event yang selanjutnya dipublikasikan melalui media massa. Dalam strategi ini humas UNIMUS melakukan strategi berupa publikasi di media massa seperti surat kabar harian Suara Merdeka, Kedaulatan Rakyat, Wawasan, dan Jawa Pos Radar Semarang. Untuk media elektronik, humas UNIMUS mempublikasikan kegiatan vaksinasi di TVRI Jawa Tengah dan TVMU (Televisi Muhammadiyah).

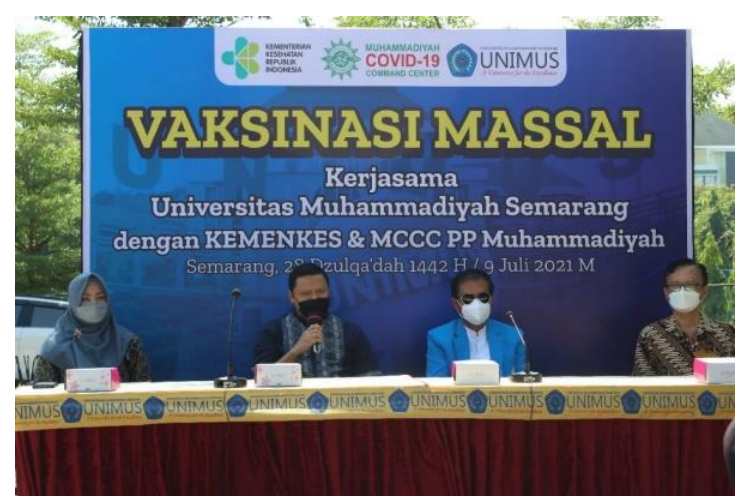

Gambar 2

\section{Jumpa Pers Pimpinan UNIMUS dengan Rekan-Rekan dari berbagai Media}

Sedangkan media digital (online), humas UNIMUS mempublikasikan melalui media online yang dimiliki oleh UNIMUS sendiri seperti website unimus.ac.id, Instagram dan Tiktok (@unimus.official), Twitter (@unimus), Youtube dan Facebook (Universitas Muhammadiyah Semarang), Telegram serta Whatsapp. Selain itu, humas UNIMUS juga mempublikasikan melalui media online seperti krjogja.com, muhammadiyah.or.id, suaramerdeka.com, pwmjateng.com, radarsemarang.jawapos.com, suara-muhammadiyah.id, serta wawasan.com dan covid19.muhammadiyah.id. Bak gayung bersambut, banyak rekan-rekan media lain yang turut mengapresiasi langkah publikasi yang dibuat oleh UNIMUS. Sehingga media 
online yang lain turut mempublikasikan kegiatan vaksinasi tersebut diantaranya republika.co.id, lintasolorayanewa.com, suarakartini.id, metrorakyat.com, halosemarang.id, ayosemarang.com, radarbangsa.co.id, sigijateng.id, jateng.tribunnews.com, hariannkri.id, suaraaisyiyah.id, serayunews.com, serta editor.id, pingpoint.co.id dan siapgrak.com. Dengan banyaknya publikasi mengenai peranan UNIMUS sebagai sentra vaksin Covid-19, menjadikan nama UNIMUS dikenal oleh publik lebih luas.

c. Kebijakan Pass Strategy Berbasis Program CSR Vaksinasi

Strategi ini merupakan strategi ketiga dalam konsep three ways strategy, dimana strategi mempengaruhi publik dengan cara memberikan kontribusi pada kegiatan sosial. Kegiatan sosial yang UNIMUS lakukan adalah dengan menjadi sentra vaksin Covid-19 dari tahap 1 hingga tuntas ke tahap 2. Jadi di tahap ini, UNIMUS concern terhadap kualitas dan kuantittas "pelayanan" agar masyarakat tetap nyaman dan cepat untuk mengikuti vaksinasi. UNIMUS mengerahkan secara optimal sumber daya yang dimiliki dari tenaga medis dan tenaga kesehatan untuk tim vaksinator dan tim screening, puluhan tim IT untuk olah data agar peserta langsung memperoleh status sudah divaksin dan tentunya mendapatkan sertifikat vaksin yang saat ini sangat diperlukan sebagai persyaratan kegiatan masyarakat. Selain itu, proses juga dibantu oleh tim kesekretariatan untuk proses registrasi, tim security, petugas kebersihan dan juru parkir agar senantiasa dalam kondisi yang kondusif, bersih, tertib dan tidak berkerumun. Lebih lanjut, UNIMUS juga menyediakan rumah karantina isolasi mandiri bagi warga Semarang yang terdeteksi positif Covid-19. Sebanyak 90 (sembilan puluh) tempat tidur disediakan UNIMUS di Gedung Laboraturium Kesehatan Masyarakat Wonolopo Mijen. Berbagai kegiatan dilaksanakan di gedung tersebut agar masyarakat yang terkonfirmasi positif Covid-19 segera sembuh dan sehat kembali.

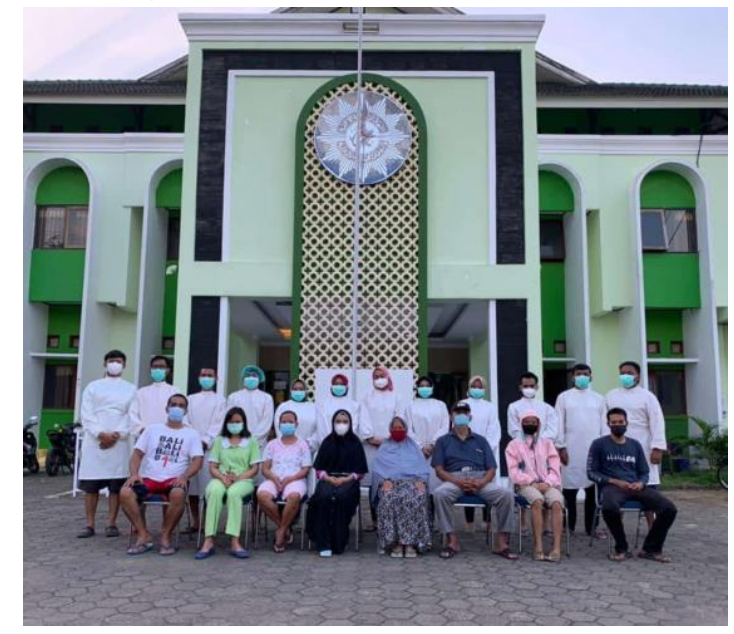

Gambar 3

\section{Gedung Karantina/Isoman Warga di Gedung Lab. Kes UNIMUS}

Beberapa kegiatan tersebut diantaranya senam pagi, pengecekan, kontrol dan screening kesehatan, konsumsi fullday dan snack bergizi, hiburan (karaoke) atau nonton film bersama namun tetap menjaga protokol kesehatan. Hal ini dilakukan agar pasien 
tidak stres sehingga imunitas bisa lebih besar ditingkatkan, sehingga lebih mudah untuk sembuh dan negatif Covid-19. Tak lupa pemberian obat dan vitamin yang dibagi menjadi tiga waktu, yakni :

a. Pagi: Fluimicir (Acetyl dosis tinggi), Ibuprofen (jika ada keluhan pusing), Antivirus (Oseltamivir), Azytromicin (sekitar < dari 10 hari), Pehavral vitamin (optional) dan Zink

b. Siang: Vitamin C 1000 (misal Redoxon), Vitamin E (contoh: Ever-E) dan Vitamin D Murni

c. Malam: Antivirus (Oseltamivir), dan Levofloxaxin

\section{Kesimpulan}

Program CSR (Corporate Social Responsibility) Vaksinasi di UNIMUS dianggap berhasil oleh Perguruan Tinggi Muhammadiyah tersebut. Hal ini dibuktikan dengan bertambahnya penerimaan mahasiswa baru UNIMUS di tahun akademik 2021/2022. Data per 6 September 2021 menunjukan bahwa sebanyak 3.067 mahasiswa baru telah ter-registrasi dan dilantik oleh Rektor pada Rapat Senat Terbuka (Kehumasan, 2021). Gencarnya promosi dan publikasi salah satunya dengan metode Marketing Public Relations yang membuat brand UNIMUS lebih dikenal publik. Sehingga Marketing Public Relations yang diterapkan dalam kegiatan Corporate Social Responsibility (CSR) Vaksinasi tersebut djabarkan menjadi tiga strategi yakni pull strategy, push strategy dan pass strategy dapat menjadi alternative promosi.

Menggunakan strategi Corporate Social Resposibility dalam upaya mempromosikan sebuah institusi menjadi bahan atau materi rekomendasi terkait teknik promosi dan publikasi yang tidak hanya dengan dalam bentuk hard selling saja. Justru dengan menerapkan Marketing Public Relations dalam bentuk Corporate Social Responsibility banyak manfaat yang diperoleh UNIMUS diantaranya semakin meningkatnya citra positif dan kuatnya brand UNIMUS di masyarakat, terjalinnya kerjasama baru antara UNIMUS dengan Kementerian Kesehatan Republik Indonesia dan Dinas Kesehatan Kota Semarang, serta membantu masyarakat khususnya warga kota Semarang agar tercipta herd immunity sehingga kasus akibat Covid-19 bisa diminimalisir. Selain itu, perusahaan atau institusi dapat mengembangkan materi CSR yang lain sesuai dengan issue terhangat yang menjadi kebutuhan di masyarakat sehingga kehadiran insitusi dapat dirasakan langsung oleh masyarakat. 


\section{BIBLIOGRAPHY}

Creswell, John W. (2010). Research design pendekatan kualitatif, kuantitatif, dan mixed. Yogyakarta: Pustaka Pelajar. Google Scholar

Moleong, Lexy J. (2007). Metode penelitian kualitatif. Bandung: Remaja Rosdakarya. Google Scholar

Putri, Adiyani Kartika, \& Aji, Gilang Gusti. (2019). Corporate social responsibility sebagai strategi marketing public relations (Studi Kasus Program CSR "Decofresh Warnai Jodipan" PT. Inti Daya Guna Aneka Warna). Commercium, 2(2). Google Scholar

Ruslan, Rosady. (2010). Manajemen public relations \& media komunikasi: Konsepsi dan aplikasi. Google Scholar

Statistik, Badan Pusat. (2020). Ekonomi Indonesia Triwulan II 2020 Turun 5, 32 Persen. Jakarta: Badan Pusat Statistik. Google Scholar

Sugiyono, Dr. (2013). Metode penelitian pendidikan pendekatan kuantitatif, kualitatif dan $R \& D$. Google Scholar

Suharto, Edi. (2008). Menggagas Standar Audit Program CSR. Disampaikan Pada, 6. Google Scholar

Wahyuningsih, Sri. (2013). Metode Penelitian Studi Kasus: Konsep, Teori Pendekatan Psikologi Komunikasi, dan Contoh Penelitiannya. Madura: UTM Press. Dalam Https://Www. Scribd. Com/Document/3824, 91045. Google Scholar

Widuhung, Selvy. (2021). Strategi Marketing Public Relations Petromindo Group Di era Pandemi Covid-19. Jurnal Public Relations (J-PR), 2(1), 1-7. Google Scholar

\section{Copyright holder:}

Anggry Windasari, Reni Shinta Dewi (2021)

First publication right:

Syntax Literate: Jurnal Ilmiah Indonesia

This article is licensed under:

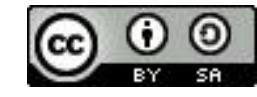

